\title{
Yearning for an Apple: The Changing Lifestyle of the Tana River Delta Communities in Kenya and Implications on Livelihoods and Conservation of Natural Resources
}

\author{
Musingo T. E. Mbuvi1 ${ }^{*}$, Leila Ndalilo², Paul Matiku³, Serah Munguti ${ }^{3}$, George Odera4 \\ ${ }^{1}$ Kenya Forestry Research Institute, Nairobi, Kenya \\ ${ }^{2}$ Coast Eco Region Research Programme, Kenya Forestry Research Institute, Malindi, Kenya \\ ${ }^{3}$ Nature Kenya, Nairobi, Kenya \\ ${ }^{4}$ Tana River Project areas, Nature Kenya, Nairobi, Kenya \\ Email: ^mtembuvi@gmail.com, leylilo@yahoo.com, matiku@naturekenya.org, advocacy@naturekenya.org, \\ tanadelta@naturekenya.org
}

How to cite this paper: Mbuvi, M.T.E., Ndalilo, L., Matiku, P., Munguti, S. and Odera, G. (2020) Yearning for an Apple: The Changing Lifestyle of the Tana River Delta Communities in Kenya and Implications on Livelihoods and Conservation of Natural Resources. Natural Resources, 11, 446-472.

https://doi.org/10.4236/nr.2020.1110027

Received: June 28, 2020

Accepted: October 23, 2020

Published: October 26, 2020

Copyright $\odot 2020$ by author(s) and Scientific Research Publishing Inc. This work is licensed under the Creative Commons Attribution International License (CC BY 4.0).

http://creativecommons.org/licenses/by/4.0/ (c) (i) Open Access

\begin{abstract}
Tana River Delta is occupied predominantly by pastoral and farming communities that inhabit defined zones in the Delta. A study was undertaken to assess changes in the lifestyle of communities living in the Delta and its implications on livelihoods and conservation of natural resources. Literature review, household questionnaires, social and resource mapping, key informant interviews, village-based focus group discussion and structured observations were used to collect data. It was evident that the delta communities are aware of the delta resources, their uses, utilization and best management options. Additionally, they were knowledgeable on the delta resources use by non-residents, the resultant conflicts and the food status in the community. They had a good understanding of the new food they would wish to have in their diets and the means of accessing them. Modernity has pushed the community to yearn for development ("Yearn for an Apple") to access foods that other parts of the country are eating, with implications on livelihoods and conservation of Delta resources. Reversing degradation and enhancing the development of the Delta area require the involvement of all stakeholders, informing and seeking the consensus of decision-makers and the real users of the Tana delta. The Government has to provide overall security and development.
\end{abstract}

\section{Keywords}

Tana Delta, Pastoralist, Development, Apple, Livelihood and Diet 


\section{Introduction}

River deltas provide multiple ecosystem services and are major centres of agriculture, industry and commerce globally [1], making them vulnerable to intensive development and unsustainable utilization [2]. These ecosystems are, however, facing degradation [2] through erosion, subsistence and subsequent flooding. River deltas are home to a half-billion or more people and have uncharacteristically high population densities and support high biodiversity [3]. Threats facing these ecosystems include damming and diversion of water, construction, irrigation and land alteration. A better understanding of delta dynamics and vulnerability and a lot of political goodwill is needed to implement adaptive delta management, restoration, and rehabilitation strategies. The involvement of stakeholders and citizens helps generate societal support for management or policy decisions [3].

Tana Delta in Kenya is of global, regional, national and local importance in the conservation of biodiversity resources and has immense social and economic value [1] [4]. These values are conflicting with dire consequences on the Delta's biodiversity, which include endemic species such as Tana River red colobus (Procolobus rufomitratus) and Tana River crested Mangabey (Cercocebus galeritus). The Tana Delta has been declared an Important Bird Area (IBA), providing habitat to more than 345 species of birds, including the threatened Basra reed warbler (Acrocephalus grisseldis) and Tana River cisticola (Cisticola restrictus). Additionally, the Delta is a stronghold for two Near Threatened, restricted-range species, Anthus melindae and Acrocephalus griseldis, while supporting one of the very few breeding sites for colonial waterbirds in Kenya. The lower Tana riverine forests are part of the Coastal Forests of Eastern Africa Hotspot [5]. They are also a major faunal link between northern and southern biogeographic zone species.

The Delta is a common use area for the communities inhabiting the area and seasonal grazers from other parts of the country and neighbouring countries [4]. The Tana Delta supports diverse livelihoods of the communities residing in the Delta, mainly the farming and the pastoralist communities comprising diverse ethnic communities [6]. The Pokomos, who are a Bantu, are farmers, while the Orma and the Wardei are nomadic and transhumant pastoralists. The farmers and the pastoralists derive their livelihoods from the Delta. The farming and pastoralism lifestyles are distinct and often in competition, often creating periodic conflicts between these two communities, particularly during the dry season.

Owing to its unique biodiversity resources, Tana Delta has a vast potential for nature-based development, such as ecotourism, beekeeping and sustainable agriculture, which has been practiced by the local people since time immemorial. Despite the huge potential for conservation of biodiversity, Tana Delta is threatened by various factors [7], which include: population growth, weak conservation efforts, changing land-use practices within and upstream of the Delta 
[4], dry season grazing area for pastoralists from as far as Wajir and Somalia, intensification of sedentary settlements, increased land selling, irrigation and rain-fed farming. Competing land-uses have often resulted in conflicts as farmers and pastoralists compete over key resources with siltation and discharge of chemical residues into the river, exerting pressure on the ecological integrity of the Delta. Additionally, the proposed developments would have far-reaching implications on biodiversity resources and community lifestyle, livelihoods and resource ownership. The situation would be worsened by the effects of strategic investment due to The Lamu Port-South Sudan-Ethiopia-Transport (LAPSSET) and global impact from countries like the Emirate of Qatar. They have expressed interest in leasing large areas of the Delta to produce food for their citizens.

The Delta community has been yearning for an apple through requiring their area to develop like the other parts of the country to ensure the betterment of humankind [8]. This development will ensure that social conditions within a nation (here a community) in which the authentic needs of its population are satisfied by the rational and sustainable use of natural resources and systems [9]. Development in Tana Delta needs to be viewed from modernization theory [9]. Modernization is a transformative process; for a society to move into modernity, its traditional structures and values must be replaced by a set of modern values. Further, it notes that modernization is an imminent process due to its systematic and transformative nature, which builds change into the social system. The term yearning for an apple has been used to describe the changing community lifestyles and subsequent desire to access modern diets and quest for a better quality life. As the delta community access the apple it may lead to degradation of TD resources if not well managed. This will call for a holistic approach to conservation and development as a means to meet the need for an apple by the delta community.

This study was part of two projects: the development of the Tana Delta Land Use Plan (LUP), which aims to ensure regulated access, sustainable use of resources and improved rangeland management that will lead to improved sustainable livelihoods, security and equity, and biodiversity conservation and the project on "Balancing water services for development and biodiversity in the Tana-Delta through support from the Darwin Initiative and Nature Kenya. The projects are being implemented in the heart of the Delta, where biodiversity is richest and access to water and land is hotly contested. The project supported several villages and two County Governments to balance water use for development and biodiversity conservation by establishing a Community Conservation Area (CCA) at the core of the Delta. It is also supported by a subset of the target 35,000 people comprising the poorest households to demonstrate to communities how to develop and diversify livelihoods within a CCA. The study assessed the Tana Delta baseline household well-being and socio-economic status, including change of lifestyles of the target communities, levels of conflicts over resources, their impact on livelihoods, and the proposed mitigation measures. The implications of local livelihoods and conservation of natural resources are hig- 
hlighted in this paper.

\section{Methodology}

\subsection{Study Area}

The study was conducted in Tana Delta, which is within the Tana Delta Sub County of Tana River County in the Coast region of Kenya, which is over 90\% Arid and Semi-Arid Lands (ASAL). It experiences bimodal rainfall pattern averaging $800-1000 \mathrm{~mm}$ p.a. The sub-county occupies $16,012 \mathrm{Km}^{2}$, out of which agricultural land is $3822 \mathrm{Km}^{2}$ and rangeland is $8964 \mathrm{Km}^{2}$ [1] [10]. The Delta ranges between two kilometers and up to forty-two kilometers in width (Figure 1). The river discharges, on average, 4000 million $\mathrm{m}^{3}$ of freshwater and 3 million

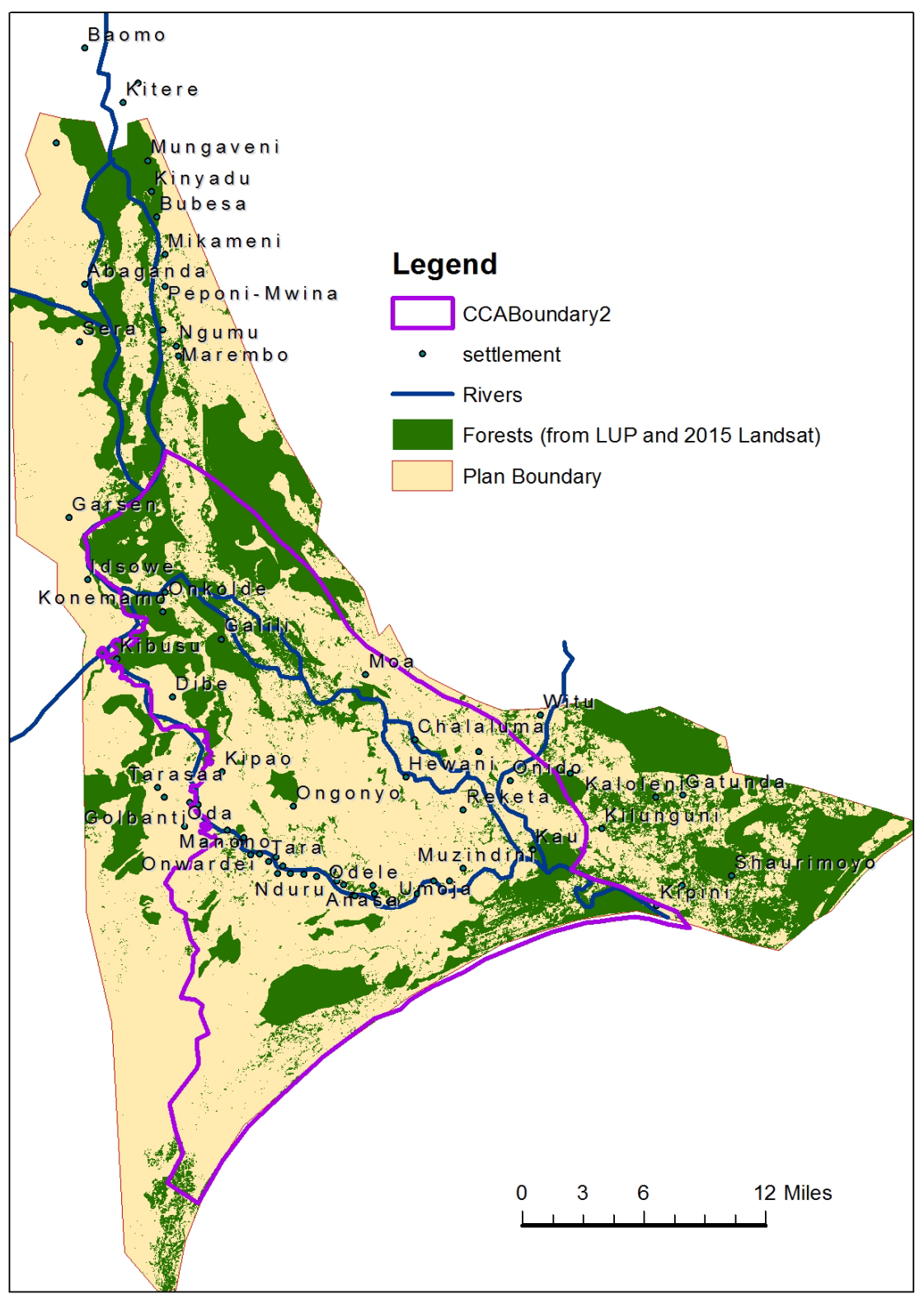

Figure 1. Tana delta and study villages (Source: Nature Kenya GIS). 
tonnes of sediments annually, which enter the ocean near Kipini at Ungwana Bay [4]. The Tana Delta area and associated ecosystems cover an area of 1300 $\mathrm{km}^{2}$. The Delta is subject to frequent flooding and changes in the network of channels and canals. The Delta has a coastal strip of $35 \mathrm{~km}$ protected by a $50 \mathrm{~m}$ high sand dune system [4].

The study area comprised of fourteen villages in Tana Delta as outlined in Table 1 .

\subsection{Data Collection Methods}

Enumerators were selected from each of the participating villages and trained alongside the community leaders on the data collection approach. The community leaders were to sensitize the community on the data collection exercise and provide social support to the enumerators. Both qualitative and quantitative approaches were used to collect data. Sixteen Focus Group Discussion (FGD) were conducted with one FGD being held in each of the fourteen villages with selected community members comprising village committee members and ordinary residents with a vast knowledge of the respective villages. An additional two FGDs

Table 1. Demography of the study villages.

\begin{tabular}{|c|c|c|c|c|}
\hline Village & Location & Major ethnic group & Major economic activity & Minor livelihood activity \\
\hline Chaluma & $\begin{array}{l}\text { Off Garsen Lamu Road, about } 7 \mathrm{~km} \text { from Witu } \\
\text { town }\end{array}$ & Orma & Pastoralism & Subsistence farming \\
\hline Handaraku & About $15 \mathrm{~km}$ North of Tarasaa town & Orma & Pastoralism & $\begin{array}{l}\text { Irrigated farming along the } \\
\text { banks of River Tana }\end{array}$ \\
\hline Golbanti & $7 \mathrm{~km}$ North West of Tarasaa town & Pokomo & Farming & Small scale businesses \\
\hline Bularahma & $\begin{array}{l}\text { Around } 10 \mathrm{~km} \text { left of the main Lamu-Malindi } \\
\text { road past Gamba Police station }\end{array}$ & Wardei & Pastoralism & $\begin{array}{l}\text { Farming, fishing and small } \\
\text { scale trade/business }\end{array}$ \\
\hline Didewaride & $12 \mathrm{~km}$ off Garsen-Lamu road & Wardei & Pastoralism & Small-scale businesses \\
\hline Hewani & $\begin{array}{l}3 \mathrm{~km} \text { off the main Lamu-Malindi Road around } \\
\text { Gamba area }\end{array}$ & Pokomo & Farming & $\begin{array}{l}\text { Beekeeping, small scale } \\
\text { businesses }\end{array}$ \\
\hline Hurara & $\begin{array}{l}\text { Located at the border between Tana River and } \\
\text { Kilifi Counties along Lamu Malindi Road }\end{array}$ & Kamba and Giriama & Farming & $\begin{array}{l}\text { Beekeeping, and small scale } \\
\text { businesses }\end{array}$ \\
\hline Nduru & $5 \mathrm{~km}$ North West of Tarassa town & Orma and Pokomo & Pastoralism and farming & \\
\hline Ozi & $\begin{array}{l}\text { Found in the lower part of TD and borders the } \\
\text { Indian Ocean }\end{array}$ & Pokomo & Farming and fishing & \\
\hline Onkolde & $\begin{array}{l}14 \mathrm{kms} \text { left of the main Lamu-Malindi road just } \\
\text { past Galili Chief's office }\end{array}$ & Orma & Pastoralism & $\begin{array}{l}\text { Small scale businesses, fishing } \\
\text { and small scale farming }\end{array}$ \\
\hline Shirikisho & $\begin{array}{l}\text { km right off the Malindi Lamu Road near } \\
\text { Minjilla }\end{array}$ & Pokomo & Farming & $\begin{array}{l}\text { Beekeeping, small scale farming } \\
\text { and small scale retail businesses }\end{array}$ \\
\hline Moa & $\begin{array}{l}6 \mathrm{~km} \text { right of the main Lamu-Malindi Road } \\
\text { around Nyongoro }\end{array}$ & $\begin{array}{l}\text { Luo, Orma, Giriama, } \\
\text { Luhya and Kamba }\end{array}$ & $\begin{array}{l}\text { Pastoralism, fishing and } \\
\text { farming }\end{array}$ & $\begin{array}{l}\text { Small scale businesses and } \\
\text { poultry farming }\end{array}$ \\
\hline Hamesa & Found within Garsen town & Orma and Wardhei & Pastoralists & Business and farming \\
\hline
\end{tabular}


were held with representatives from all the villages at the beginning and the end for feedback and validation. Key Informant Interviews (KII) were conducted with officers from Nature Kenya, representatives of local NGOs, Area Chiefs and village elders. Participatory Rural Appraisal (PRA) tools, including well-being ranking and resource mapping, were also used to obtain qualitative data.

PRA tools were used: household well-being characterization was done for each village and later consolidated to a general well-being ranks and characterization for the entire Delta area (Appendix A). The households were classified into four broad categories and the indicators for ranking households were based on the five capitals and included; livestock number, ability to educate children, authority and social status, farming type and farming area. The respondents indicated that there is a fifth category that has no means of survival that survives through God's grace with support from well-wishers. The ranks were; Rank A: perceived to be well-off or rich (in Kiswahili ${ }^{1}$ referred to as Tajiri), Rank B: perceived to be moderately well-off or rich (in Kiswahili referred to as Tajiri wa kadri/Tajiri kiasi), Rank C: perceived to be slightly well-off or poor (in Kiswahili referred to as Maskini) and Rank D: perceived to be least-well-off or very poor (in Kiswahili referred to as Maskini sana). Social mapping was done to identify the delta stakeholders, resources and conflicts, undertake diet profiling and list what the communities are eating, their sources and identify the new diets they would wish to eat indicating how they would access the diets.

Besides, a total of 631 households were interviewed using semi-structured questionnaires to obtain community perceptions on natural resource management, land ownership, livelihood and income sources, diversity of diets and conflict management. The results were analyzed using MS-Excel computer software and subjected to descriptive statistics involving computation of sums, means, frequencies and percentages and presented through charts and graphs.

\section{Results and Discussion}

\subsection{Characterisation of Respondents Household Well-Being Levels}

Household well-being ranking indicated that the majority of communities living in Tana Delta were either poor (41\%), very poor (39\%) with the well-off being $15 \%$ and the most well-off (Rank A) being 5\%. The KI and FGD attributed this situation to a lack of competitive market prices for their products, drought and diseases, which affect both crop farming and pastoralism negatively.

The high levels of poverty were attributed to inadequate rainfall that has limited the productivity of livelihood activities, mainly crop farming and livestock keeping, as well as incidences of conflicts in the Tana Delta, which disrupts livelihood activities. The findings of this study compare with earlier studies [11] which found that despite continued efforts to enhance agricultural productivity and the increased momentum towards globalization, along with increasing scarcity of land and water resources, poverty and resource degradation have in-

${ }^{1}$ This is the official language for Kenya. 
creased in some marginalised areas, especially in sub-Saharan Africa.

\subsection{Status of Natural Resource in Tana Delta and Community Conserved Areas}

Respondents expressed concern that the status of natural resources in Tana Delta has continued to deteriorate over time, and this was attributed to anthropogenic factors. These include deforestation (66\%), change of river course (18\%) and overgrazing by livestock owned by immigrants $(16 \%)$, which was largely blamed for perrenial drought and resource use conflicts witnessed in Tana Delta. Flooding remains a challenge though the community did not mention it. These findings vary from earlier studies [12] which summarised the main threats to the conservation of Tana Delta as poor governance, sectoral approach to resource management, lack of community access and participation in decision making, lack of access to environmental information for local communities, lack of a legal remedy and land tenure insecurity.

To address these challenges and improve the management of Tana Delta's natural resources, respondents proposed strict enforcement of rules and regulations governing the use of Tana Delta resources, community sensitization on sustainable natural resource management and implementation of afforestation and reforestation programmes. They also proposed restricting grazing of livestock from other areas, the introduction of alternative income-generating activities to relieve pressure on natural resources, non-interference with the river course and improved management of CCAs. Respondents expressed willingness to have the CCA well managed, with the majority (66\%) proposing community-based management as the best management strategy. Another 34\% proposed multi-stakeholder management to enhance accountability in the management of CCAs.

\subsection{Land Ownership and Use}

About $27 \%$ of land in Tana Delta was perceived by household respondents to be owned individually, while $73 \%$ as owned communally. In 2012, communal land ownership was over $80 \%$ [10]. The community recognizes community land ownership/tenure system. Of those with individual land ownership, only 13\% have title deeds. Another 54\% have sale agreements, 31\% allotment letters and $2 \%$ lease certificate. As community land ownership decreases and individual ownership increases, there is a likelihood of non-delta residents purchasing land. This is likely to escalate resource use conflicts and more land appropriation. Furthermore, the high number of sale agreements is a pointer to increasing cases of land sub-division and sale that was mainly attributed to the strategic location of the Delta as a major component of the Lamu Port Southern Sudan-Ethiopia Transport (LAPSSET) corridor project being spearheaded by the Government of Kenya. A study conducted earlier [12] concurs that the proposed Lamu Port will have severe environmental consequences on the Tana Delta.

Respondents further recommended land adjudication as a remedy for ensur- 
ing sustainable land management as well as averting the high cases of land-use conflicts recorded in Tana Delta, since most residents do not have land ownership documents. Though a positive move, individual land ownership is likely to have a negative impact on livestock grazing, the major community land use. Such a move would therefore require to be supported by awareness creation, the introduction of more profitable alternative land-use activities to replace livestock grazing and conserve wildlife conservation areas.

The average size of land used per household was 19.5 acres, land was allocated for various uses as follows; grazing area (48\%), the area under trees (25\%), crops (18\%) and 9\% under homestead. The land was generally said to be adequate, but land use planning at the location and village level is still a major challenge and could be addressed through the planned implementation of The Tana Delta land-use plan. There were reported cases of more investors coming into the Delta to engage in large scale commercial farming, a scenario that is likely to exacerbate conflicts as competition for land among farmers and pastoralists escalates as any increase in crop production and urbanization is expected to reduce grazing land.

These findings compare with past studies [13], which established that the ecological balance of the Tana Delta, which has been maintained by traditional land-use practices, is threatened by ill-conceived and unsustainable development projects in the upper catchment and at the Delta. Integrating environmental considerations into the management and the development of the delta area, to reconcile interests and ensuring that the development of the natural resources is in harmony with the ecological processes [13].

\subsection{Main Livelihood Activities and Sources of Income}

Farming was the main source of livelihood practiced by $71 \%$ of households in Tana Delta, while salary was the least source of livelihood (2\%). Farming is, however, mainly practiced for subsistence with the only surplus produce sold in local markets (Figure 2), contributing less to household cash income.

The community, as indicated through FGD and KII, has numerous livelihood activities as outlined in Appendix B. It was evident that the community has a high diversity of livelihood sources [14]. Additionally, the organizations were aware of the challenges facing these livelihood activities and knew the best option to increase the livelihood sources. All Gender was involved in the livelihood activities, with a few being gender-specific.

\section{Challenges Affecting Livelihood Activities}

The livelihood/income-generating activities mentioned above, however, face several challenges that affect their productivity. Crop invasion by wild animals and diversion of Tana River was ranked (highest frequency) as the greatest challenges to productivity in Tana Delta (Table 2). Respondents recommended ways of addressing them through capacity building, provision of farm implements and improved road network and formation of marketing 


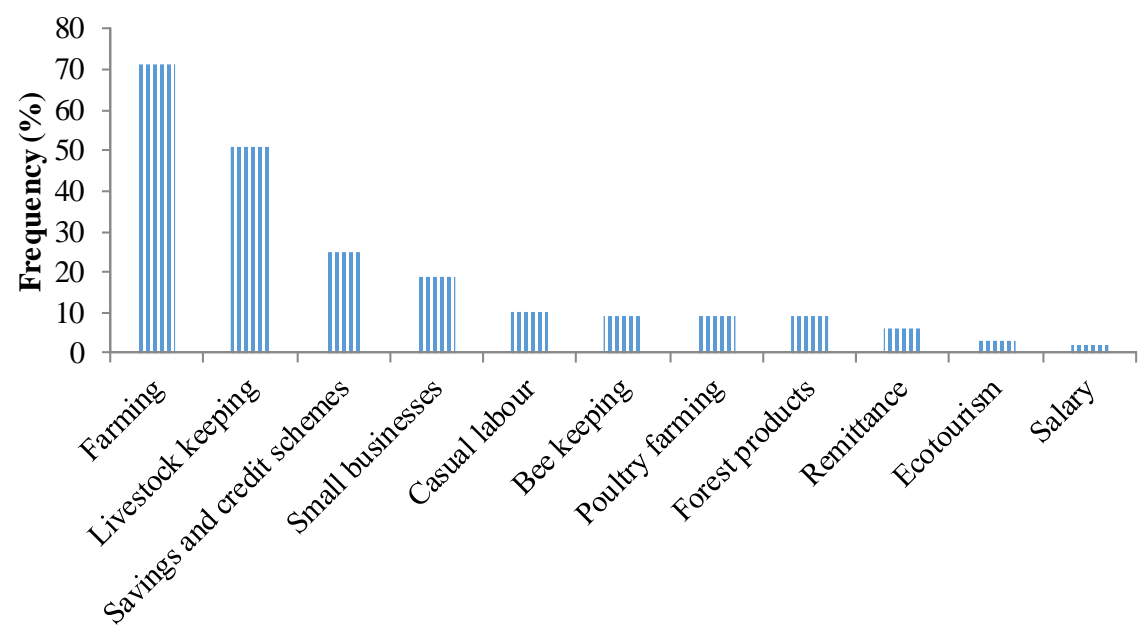

Sources of livelihood

Figure 2. Main sources of livelihoods (Source: Field survey data).

Table 2. Challenges which limit productivity.

\begin{tabular}{cc}
\hline Challenge & Frequency (\%) \\
\hline Inadequate rainfall & 82 \\
Crop and livestock diseases & 23 \\
Attack of crops by wild animals & 20 \\
Diversion of Tana river & 14 \\
Inadequate capital & 10 \\
Inadequate crop farming skills & 10 \\
Poor market prices & 9 \\
Inadequate pasture & 8 \\
Ethnic conflicts & 8 \\
Inadequate arable land & 7 \\
An influx of livestock from outside the Delta & 5 \\
Inadequate quality seeds & 2 \\
Inadequate animal husbandry skills & 2 \\
\hline
\end{tabular}

cooperatives. This confirms the observation by [14] that in the Tana River Basin, livelihoods are clearly and inextricably linked to the natural environment in a co-evolving way such that people influence and are influenced by land cover.

The delta economy is agriculture-based with increased interest in improved poultry and cash crops. FGD indicated that this requires technical support to maximize production and its livelihood contribution as was similarly recommended earlier [10].

\subsection{Income Sources in the Delta}

Pastoral communities mainly practice livestock keeping for commercial value. 
The majority of this livestock is, however, owned by people living outside the Delta; hence the benefits accrued do not directly translate to enhanced community livelihoods in the Tana Delta. This explains why farming ranked as the most important livelihood activity (Figure 2), although livestock farming generates more income (Figure 3).

Livestock keeping was the highest source of income (Ksh. 142,543 per annum) followed by savings and credit schemes with poultry farming being the least source of income at Ksh. 14,570. Analysis of average household income per annum per village revealed that male-headed households generated more income from the various livelihood activities as compared to the female-headed households (Table 3).

This could be attributed to lower women participation in major income generation activities, notably livestock keeping, savings and credit schemes, fishing and fish farming, forest products and small businesses (Table 4) by women. Respondents were of the opinion that women spend a substantial amount of time performing domestic chores and taking care of children and are thus often excluded from other development activities. Women's participation was very high in poultry keeping and farming. Affirmative action could enhance their participation in these and other IGAs. These findings compare with earlier observation [15] which found that men own more and higher value assets than women and empirical evidence shows that ownership and control of assets affect household income.

\subsection{Diversity of Diets}

The community has maize and rice as their staple food, but they would wish to eat foods that were hitherto considered for urban populations. This has been caused by good road network and Information Technology, which have increased their level of interaction with communities from outside the Delta.

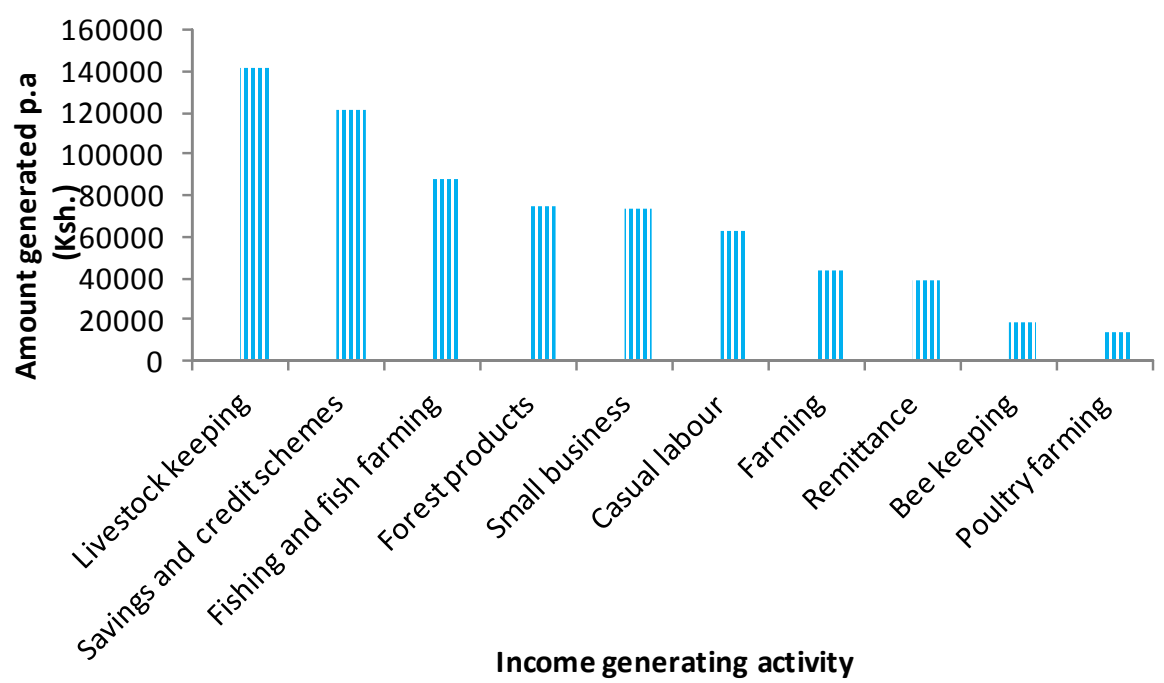

Figure 3. Main income-generating activities (Source: Field survey data). 
Table 3. Average household income earned in 2017.

\begin{tabular}{cccc}
\hline & & Average household income earned in 2017 (Ksh.) \\
\cline { 3 - 4 } Village & Main IGA & Male headed households & $\begin{array}{c}\text { Female-headed } \\
\text { households }\end{array}$ \\
\hline Bularahma & Livestock keeping & 25,179 & 27,771 \\
Onkolde & Livestock keeping & 54,714 & 73,500 \\
Moa & Fishing and Farming & 43,510 & 39,000 \\
Shirikisho & Farming and Beekeeping & 57,344 & 33,000 \\
Idsowe & Farming and Trading & 54,440 & 17,500 \\
Golbanti & Farming & 22,339 & 23,000 \\
Nduru & Farming and Livestock keeping & 159,419 & 40,000 \\
Hewani & Farming & 40,218 & 22,632 \\
Hamesa & Farming and pastoralism & 95,581 & 67,969 \\
Hurara & Farming and Beekeeping & 59,467 & 55,252 \\
Handaraku & Livestock keeping & 125,000 & 31,938 \\
Ozi & Farming and fishing & 99,789 & 39,312 \\
Didewaride & Livestock keeping and fishing & 34,313 & HH recorded) \\
Chalaluma & Livestock keeping & 48,238 & 54,929 \\
Average & & 71,466 & 34,559 \\
\hline & & & $($ No female-headed \\
& & &
\end{tabular}

Table 4. Gender representation in main IGAs.

\begin{tabular}{ccc}
\hline Income Generating Activity & \% Men & \% Women \\
\hline Livestock keeping & 71 & 29 \\
Farming & 53 & 47 \\
Beekeeping & 73 & 27 \\
Fishing and fish farming & 84 & 16 \\
Casual labour & 88 & 12 \\
Small business & 71 & 29 \\
Forest products & 81 & 19 \\
Poultry farming & 32 & 68 \\
Savings and credit schemes & 71 & 29 \\
\hline
\end{tabular}

\subsubsection{Main Types of Food Eaten}

The type of food eaten is often used as a proxy of food security and the well-being status of a community. The main types of foods consumed by households in the Tana Delta are highlighted in Figure 4.

Maize and rice were the leading types of food consumed by $90 \%$ and $81 \%$ of the community respectively, while sorghum and honey were least consumed by $4 \%$ and $2 \%$ of the community respectively. The diversity of diets was assessed across the 14 sampled villages with results indicating variation in the level of 


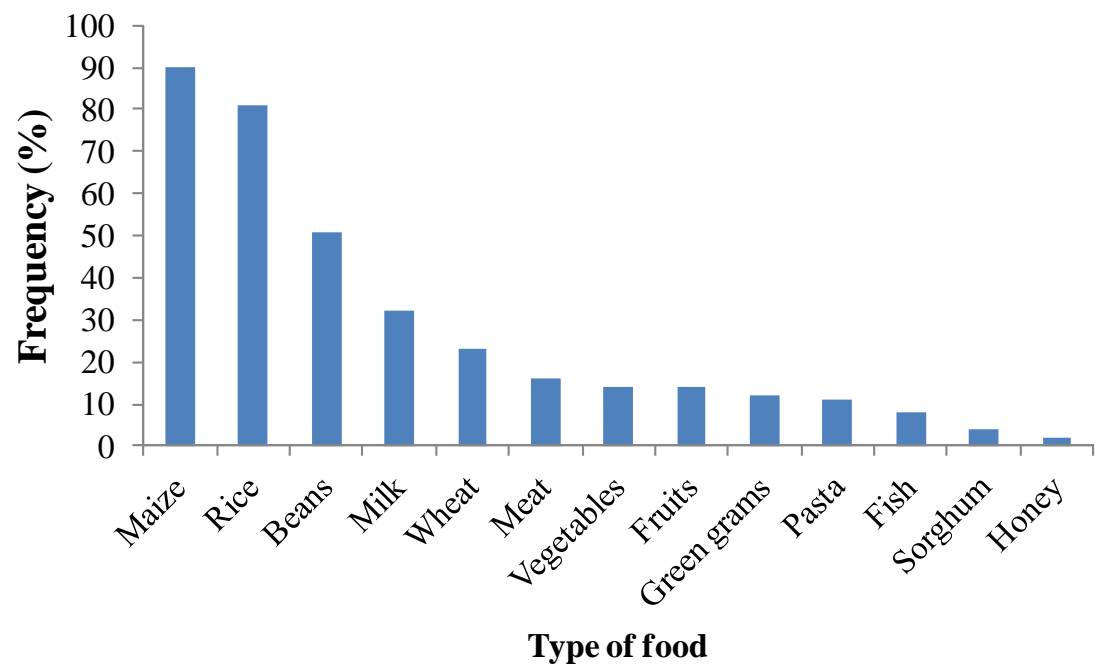

Figure 4. Main Types of food eaten in the Tana Delta (Source: Field survey data).

consumption of the main food types based on each village's main economic activities, relief food support and well-being status (Table 5).

Maize and rice were the most consumed foods, followed by beans. Consumption of vegetables and fruits was generally low, hence causing a major challenge to nutrition, as was exhibited by malnutrition among children. The World Food Programme (WFP) estimates that about 10 million people experience nutritional deficiency diseases due to a lack of access to quality foods [16].

Although the major foods consumed were found to be similar, the extent of consumption varied across the villages, depending on their socio-economic activities. All members of the household consume common meals; hence there were no food preferences recorded based on Gender and age. This was further exacerbated by the high cost of food, which makes household members eat available foods; $71 \%$ of the food eaten was purchased from shops while only $26 \%$ was produced on farms. Another 3\% of the food eaten was obtained from relief agencies. Respondents expressed concern that households spend an average of Ksh. 25,186, which comprise about $90 \%$ of their household income on food with only $10 \%$ left to take care of other household expenses. The households require more activities to provide cash income to enable them to continue accessing food, which is mainly bought. Special measures need to be put in place to address the needs of poor households who may not have cash as means of securing their food security. In 2008, Kenya was found to suffer from chronic food insecurity with the majority of those affected being the very poor [17].

\subsubsection{Annual Food Calendar}

Food scarcity is a major challenge in the Delta with $35 \%$ of households reporting that they often go for more than 3 weeks without food. Another $11 \%$ of the households go for up to 1 week without food, while $17 \%$ reported going without food for between 2 - 3 weeks. Households have, however, developed mechanisms for coping during periods of food insufficiency; $48 \%$ borrow food from neighbours, 
Table 5. Types of food eaten segregated into villages.

\begin{tabular}{|c|c|c|c|c|c|c|c|c|c|c|c|c|c|}
\hline \multirow{2}{*}{ Village } & \multicolumn{13}{|c|}{ Number of people consuming each food (\%) } \\
\hline & Maize & Rice & Beans & Milk & Wheat & Meat & Vegetables & Fruits & Green grams & Pasta & Fish & Honey & Sorghum \\
\hline Bularahma & 67 & 98 & 65 & 70 & 47 & 63 & 0 & 0 & 2 & 15 & 0 & 0 & 0 \\
\hline Onkolde & 87 & 30 & 50 & 73 & 3 & 20 & 0 & 3 & 3 & 0 & 0 & 0 & 0 \\
\hline Moa & 82 & 45 & 7 & 67 & 22 & 23 & 15 & 5 & 0 & 0 & 22 & & 0 \\
\hline Shirikisho & 98 & 80 & 50 & 5 & 42 & 2 & 5 & 7 & 5 & 38 & 3 & 7 & 0 \\
\hline Idsowe & 100 & 93 & 93 & 17 & 47 & 33 & 47 & 47 & 0 & 0 & 0 & 13 & 0 \\
\hline Golbanti & 97 & 80 & 37 & 30 & 23 & 17 & 60 & 0 & 23 & 0 & 17 & 3 & 0 \\
\hline Nduru & 100 & 100 & 62 & 10 & 17 & 23 & 0 & 3 & 0 & 0 & 50 & 0 & 0 \\
\hline Hewani & 98 & 85 & 35 & 7 & 7 & 2 & 5 & 8 & 60 & 5 & 3 & 5 & 43 \\
\hline Hamesa & 93 & 97 & 97 & 7 & 10 & 3 & 17 & 0 & 7 & 20 & 0 & 0 & 0 \\
\hline Hurara & 100 & 58 & 60 & 0 & 27 & 7 & 42 & 2 & 8 & 5 & 3 & 0 & 0 \\
\hline Handaraku & 97 & 93 & 50 & 83 & 37 & 20 & 27 & 10 & 43 & 50 & 0 & 0 & 0 \\
\hline Ozi & 63 & 100 & 35 & 1 & 33 & 3 & 5 & 93 & 15 & 7 & 8 & 0 & 0 \\
\hline Didewaride & 95 & 85 & 62 & 10 & 0 & 17 & 3 & 0 & 0 & 18 & 0 & 0 & 0 \\
\hline Chalaluma & 100 & 93 & 90 & 80 & 23 & 10 & 20 & 3 & 36 & 27 & 3 & 0 & 0 \\
\hline
\end{tabular}

$32 \%$ reduce the amount of food consumed, 19\% depend on relief food and $1 \%$ obtain food items on credit from local shops. The National Drought Management Authority (NDMA) estimates that about 100,000 people in Tana River County, majority of whom are found within the Tana Delta, are hunger stricken due to failure of both short rains and long rains for two successive years and urgent interventions are needed to save lives [18].

Each village had a good knowledge of the food they eat throughout the year as represented by the annual food calendar for Chalaluma, as outlined in Table 6, which demonstrates that the community is faced with severe food shortage for eight months in a year.

The community indicated food scarcity was due to drought and poor livestock health. During the period of food scarcity, people may take up to four days without food. The scenario in Shirikisho village show how communities in the Delta cope with food shortage (Table 7).

\subsubsection{Diet Analysis}

Diet was indicative of the food eaten by the community. It was indicated that the communities in Tana Delta have a diversified diet that is not gender-specific with both men and women contributing equally to their provision, as shown in Table 8. The community listed the following as the main foods eaten by them; Cassava, Sweet potatoes, pineapples, Bananas, Maduga, watermelon and wild fruits (Nkindu, nyambebe, Kaa and Njiga). They indicated that there are minimal gender and ethnic diet differentiations, but well-being differences are significant. Fishing is done in May, June and July. The households with employed 
Table 6. Annual food calendar for Chalaluma village as perceived by FGD.

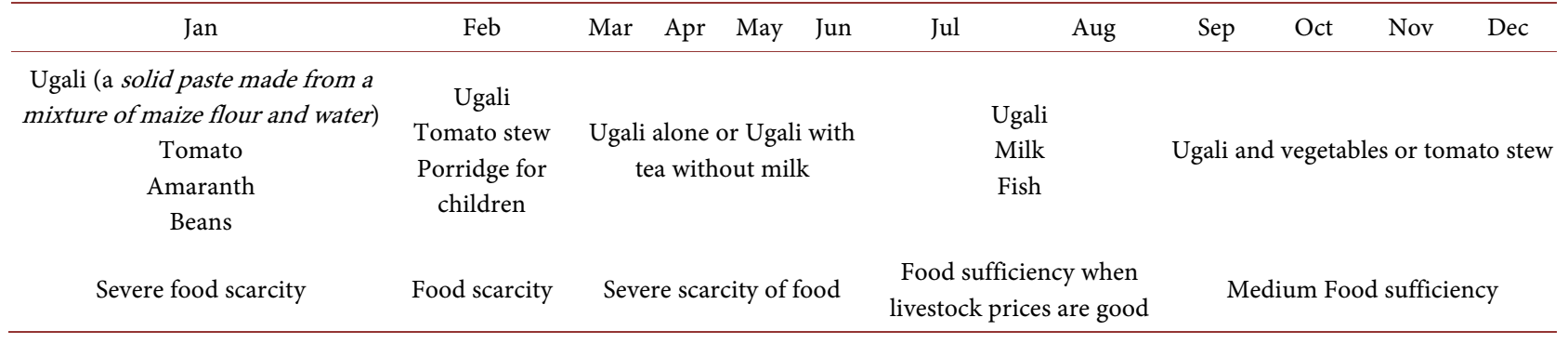

Table 7. Sources of the different food types provided to households in Shirikisho village.

\begin{tabular}{cccccccccc}
\hline Stakeholder/Support & Maise & Beans & Rice & Cooking oil & Meat & $\begin{array}{c}\text { Finger } \\
\text { Millet }\end{array}$ & $\begin{array}{c}\text { Green } \\
\text { Grams }\end{array}$ & $\begin{array}{c}\text { Maise } \\
\text { flour }\end{array}$ \\
\hline National Government & $\sqrt{ }$ & $\sqrt{ }$ & - & $\sqrt{ }$ & - & - & - & - \\
County Government & $\sqrt{ }$ & $\sqrt{ }$ & $\sqrt{ }$ & $\sqrt{ }$ & - & - & - & - \\
$\quad$ Red Cross & $\sqrt{ }$ & $\sqrt{ }$ & $\sqrt{ }$ & $\sqrt{ }$ & $\sqrt{ }$ & $\sqrt{ }$ & - & $\sqrt{ }$ \\
Nature Kenya & - & - & - & - & - & - & $\sqrt{ }$ & - \\
Turkey Government & - & - & - & - & $\sqrt{ }$ & - & - & - \\
Mama Hong NGO & - & $\sqrt{ }$ & - & - & - & - & - & $\sqrt{ }$ \\
\hline
\end{tabular}

Table 8. The foods which are eaten by the different Gender in Idsowe, Nduru and Shirikisho villages.

\begin{tabular}{|c|c|c|c|c|c|c|c|}
\hline Diet & Children & Girls & Boys & Women & Men & Old men & Old Women \\
\hline Bananas & $\sqrt{ }$ & $\sqrt{ }$ & $\sqrt{ }$ & $\sqrt{ }$ & $\sqrt{ }$ & $\sqrt{ }$ & $\sqrt{ }$ \\
\hline Beans & - & $\sqrt{ }$ & $\sqrt{ }$ & $\sqrt{ }$ & $\sqrt{ }$ & $\sqrt{ }$ & $\sqrt{ }$ \\
\hline Biriani (Rice meal) & $\sqrt{ }$ & $\sqrt{ }$ & $\sqrt{ }$ & $\sqrt{ }$ & $\sqrt{ }$ & $\sqrt{ }$ & $\sqrt{ }$ \\
\hline Chapati & $\sqrt{ }$ & $\sqrt{ }$ & $\sqrt{ }$ & $\sqrt{ }$ & $\sqrt{ }$ & $\sqrt{ }$ & $\sqrt{ }$ \\
\hline Eggs & $\sqrt{ }$ & $\sqrt{ }$ & - & - & - & - & $\sqrt{ }$ \\
\hline Finger Millet & - & - & - & - & $\sqrt{ }$ & - & - \\
\hline Fish & - & - & $\sqrt{ }$ & $\sqrt{ }$ & $\sqrt{ }$ & $\sqrt{ }$ & $\sqrt{ }$ \\
\hline Fruits & $\sqrt{ }$ & $\sqrt{ }$ & $\sqrt{ }$ & $\sqrt{ }$ & $\sqrt{ }$ & $\sqrt{ }$ & $\sqrt{ }$ \\
\hline Githeri & - & - & $\sqrt{ }$ & - & - & - & - \\
\hline Green grams & $\sqrt{ }$ & $\sqrt{ }$ & $\sqrt{ }$ & $\sqrt{ }$ & $\sqrt{ }$ & $\sqrt{ }$ & $\sqrt{ }$ \\
\hline Kales & - & $\sqrt{ }$ & $\sqrt{ }$ & $\sqrt{ }$ & $\sqrt{ }$ & $\sqrt{ }$ & $\sqrt{ }$ \\
\hline Mangoes & - & - & $\sqrt{ }$ & $\sqrt{ }$ & - & - & - \\
\hline Meat & - & $\sqrt{ }$ & $\sqrt{ }$ & - & $\sqrt{ }$ & & - \\
\hline Milk & $\sqrt{ }$ & $\sqrt{ }$ & - & $\sqrt{ }$ & - & - & $\sqrt{ }$ \\
\hline Porridge & $\sqrt{ }$ & $\sqrt{ }$ & - & - & - & $\sqrt{ }$ & $\sqrt{ }$ \\
\hline Potatoes & $\sqrt{ }$ & $\sqrt{ }$ & - & - & - & - & - \\
\hline Soup & - & - & - & - & - & - & $\sqrt{ }$ \\
\hline Spaghetti & $\sqrt{ }$ & $\sqrt{ }$ & $\sqrt{ }$ & $\sqrt{ }$ & $\sqrt{ }$ & $\sqrt{ }$ & $\sqrt{ }$ \\
\hline Tea & $\sqrt{ }$ & $\sqrt{ }$ & $\sqrt{ }$ & $\sqrt{ }$ & $\sqrt{ }$ & $\sqrt{ }$ & $\sqrt{ }$ \\
\hline Ugali & - & - & $\sqrt{ }$ & - & $\sqrt{ }$ & $\sqrt{ }$ & $\sqrt{ }$ \\
\hline Vegetables & $\sqrt{ }$ & $\sqrt{ }$ & $\sqrt{ }$ & $\sqrt{ }$ & $\sqrt{ }$ & $\sqrt{ }$ & $\sqrt{ }$ \\
\hline Viazi (sweet potatoes) & $\sqrt{ }$ & $\sqrt{ }$ & $\sqrt{ }$ & $\sqrt{ }$ & $\sqrt{ }$ & $\sqrt{ }$ & $\sqrt{ }$ \\
\hline
\end{tabular}


members eat modern food types comprising of the following: rice, chapatti, pasta/spaghetti, milk, blue band (margarine) and cooking oil. The diets are becoming modernized as local communities interact with communities from outside the Delta and the improved road network facilitates the movement of goods and services into and outside the Delta.

\subsubsection{New Diets (The Apple)}

About $91 \%$ of the respondents said they were willing to diversify their diets. They further suggested that they would wish to include meat (41\%), vegetables (23\%), pasta (22\%), wheat (19\%), fruits (15\%), milk (14\%), eggs (13\%), rice (9\%) and beans $(8 \%)$. Other foods that residents would like to include in their diet were millet, mushrooms and honey at $2 \%$ each. Respondents recommended the introduction of poultry keeping in the area to provide them with eggs, which they mentioned was highly nutritious for children and easy to prepare. They further emphasized that although vegetables and fruits were being imported from other regions and sold in local markets, the prices were often very high and beyond their reach. Millet (for making porridge) and mushrooms were said to be highly nutritious for children and the elderly, while honey was preferred for its medicinal value. Sorghum is given as relief food by humanitarian organizations such as the Kenya Red Cross Society [19] but has been introduced as food and cash crop in Hurara village where it has already been introduced in the community's diet and has been instrumental in improving the nutritional status of children and elderly who consume it as porridge. The above indicates that the community are aware of what diet they need as outlined by FGD and KI (Table 9).

Table 9. New diet the delta community would wish to eat.

\begin{tabular}{ccc}
\hline Food & Gender interested & Why \\
\hline Apple & Men, Women, Children, Girls and Boys & We cannot produce expensive to buy \\
Avocado & Men, Women, Children, Girls and Boys & We cannot produce \\
Biriani & Women, Men and Boys & Gives energy \\
Bread & All Gender & Light food \\
Cake & All Gender & Most people would like to eat it \\
Camel meat & Men, Women, Children, Girls and Boys & We do not have Camel \\
Carrots & All & Improve eye sights \\
Cassava & All Gender & Feed all and takes a long time to be digested \\
Chapati & We cannot produce \\
Chicken and Chips & Men, Women, Children, Girls and Boys & The community would wish to eat it \\
Coconut & All & We cannot afford but Gives energy \\
Dates & All Gender & We cannot produce \\
Eggs & Increase blood and control pressure
\end{tabular}




\section{Continued}

Fermented milk (Kirori, Kalba)

Finger millet

Green grams

Halwa

Mokimo*

Omena (sardines)

Oranges

Pasta/Makoronya

Peanuts

Pigeon peas

Pineapple

Pizza

Spaghetti

Spinach

Sweet potatoes

Yogurt
Old men and Old Women

Men, Women, Children, Girls and Boys

All

All

Both Gender

Men and Boys

Men, Women, Children, Girls and Boys

All

Men, Women, Children, Girls and Boys

All

Men, Women, Children, Girls and Boys

Men and Women

All Gender

All Gender

All
Energy food

\author{
We cannot produce \\ Relish and cheap to buy \\ Sweet and appetizer \\ Gives energy \\ Gives energy \\ We cannot produce \\ Good food \\ We do not produce
}

We cannot produce, but it's a relish

We cannot afford

Gives energy

Easy to cook

A new food type for good health.

Train communities how to prepare them

Energy giving

We do not have skills and industrial marketing

${ }^{*}$ A cooked mixture of maize, beans, potatoes and greens.

\subsection{Conflicts in Tana Delta}

Respondents (41\%) alluded that there are resource use conflicts and conforms to earlier observations [4] [6] [20]. The perceived types of conflicts by the households included; ethnic (41\%), Resource use (24\%), Human-wildlife (19\%), land-use conflicts (14\%) and conflicts between TARDA and local communities (2\%). Conflicts disrupt rural livelihoods and destroy investments, uproot households from their homesteads, creating deep-rooted ethnic tensions. Boundary disputes were highlighted as a cause of conflicts in the Tana Delta [19].

These conflicts were mainly driven by inadequate land, ethnic animosity among diverse communities living in Tana Delta, scarce pasture and water resources and an influx of livestock from other areas (Figure 5). These findings confirm the causes of conflicts highlighted by [19].

Additionally, an analysis of the conflicts, their causes and proposed mitigation measures perceived by the community was provided through Focus Group Discussion and Key informants and outlined in Appendix C. Crop losses were mainly attributed to resource use conflicts that result in livestock owned by pastoralists invading crop farms in search of pasture hence causing destruction. These findings compare with earlier studies [19] which established that conflicts in Tana Delta are largely fuelled by conflicting land uses whereby pastoralists believe in a communal land system that would support their lifestyle while the farmers advocate for land adjudication of individual freeholds. One of the causes for the eruption of inter-tribal conflicts in the Tana Delta is connected to the 


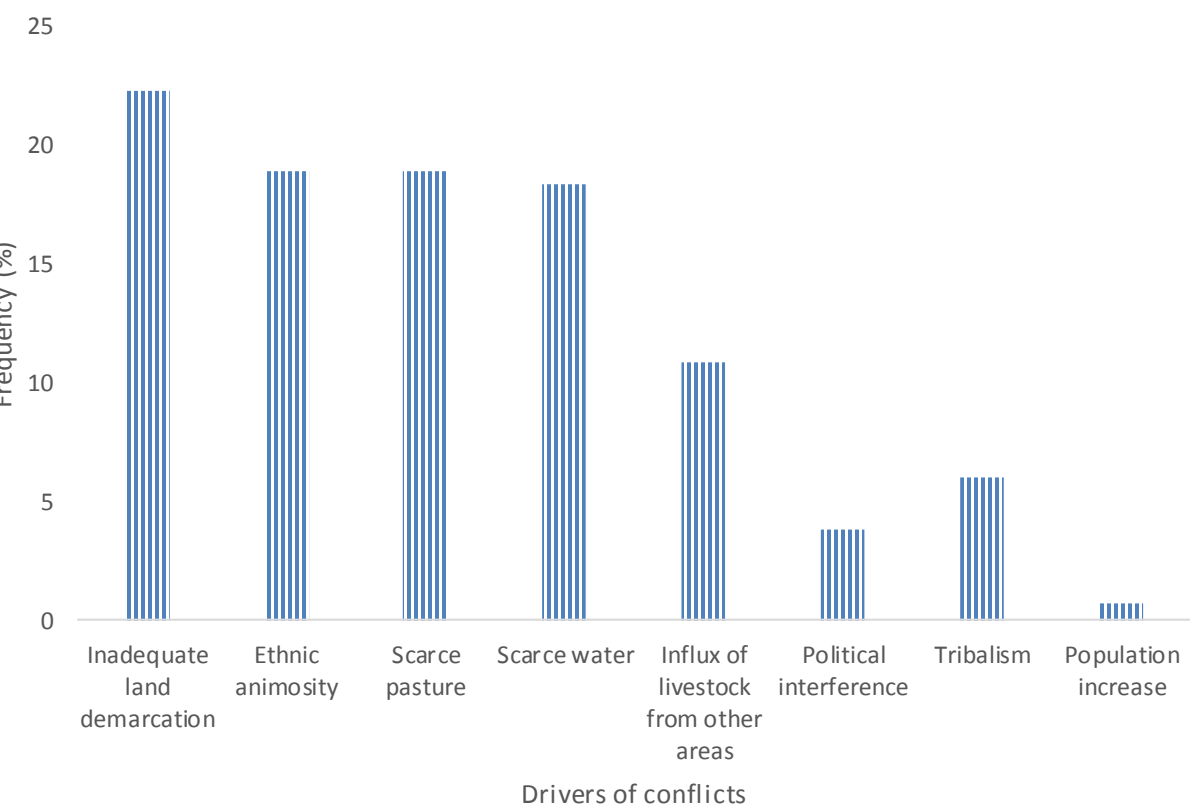

Figure 5. Drivers of conflicts in the Tana Delta (Source: Field survey data).

activities of the land adjudication commission [21]. The study further listed politics as another major cause of conflicts in the Tana Delta. To reverse the losses, respondents suggested several means of managing conflicts, including; sensitization of local communities on the importance of peaceful co-existence among various communities living in Tana Delta through local community leaders and the implementation of the land-use plan.

Conflicts often result in loss of essential livelihood assets, thus impoverishing local communities even further. On average, households living in Tana Delta lose the following assets per annum as a result of conflicts (Table 10).

These results compare with past studies [21] which summarised the main impacts of conflicts in Tana Delta as loss of lives, loss of property and livelihoods, increased levels of poverty, increase in the number of school dropouts, displacement and loss of economic growth.

\subsection{Interventions to Access the Apple}

The changing livelihoods and lifestyle in the Delta areas were evident. In addition to the existing IGAS, the communities are desirous of living a life that other global citizens are living. In this paper, this is presented by the yearning for an apple expressed during village social mapping, among many other livelihood and lifestyle changes households desired. The apple fruit in Kenya is imported and locally grown in Kiambu, Kitale and Nandi counties; the nearest county where the fruit is grown from Tana Delta is over 600 kilometres away. The numerous income-generating activities (Table 11) through Nature Kenya have contributed significantly to local livelihoods, as indicated by $70 \%$ of the respondents. This was perceived as a key step in contributing considerably towards the community accessing the new diets (Apple). 
Table 10. Average household assets lost as a result of conflicts.

\begin{tabular}{ccc}
\hline S/No. & Asset & Quantity lost \\
\hline 1 & Crops (maize, green grams, watermelons and mangoes) & $48,429 \mathrm{~kg}$ \\
2 & Cows & 380 \\
3 & Fish & $23,367 \mathrm{~kg}$ \\
4 & Poultry & 2272 \\
5 & Goats & 1173 \\
6 & Sheep & 16 \\
7 & Donkeys & 6 \\
\hline
\end{tabular}

Table 11. Existing IGAs supported by the project.

\begin{tabular}{|c|c|c|}
\hline IGA & Villages supported & Nature of support \\
\hline Crop farming & $\begin{array}{l}\text { Hewani, Wema } \\
\text { and Chalaluma }\end{array}$ & $\begin{array}{l}\text { - Provision of seeds, fertilizers, ploughing and harrowing services } \\
\text { - Business management training } \\
\text { - Solar installation }\end{array}$ \\
\hline \multirow[t]{2}{*}{ Livestock keeping } & Onkolde and Bularahma & $\begin{array}{l}\text { - Construction of cattle dip and purchase of acaricides } \\
\text { - Provision of milk equipment } \\
\text { - Installation of solar energy for the village in centralized locations for mobile phone charging } \\
\text { to ease communication }\end{array}$ \\
\hline & Didewaride & - Planned a livestock business scheme \\
\hline Poultry farming & Moa and Hewani & $\begin{array}{l}\text { - Construction of poultry houses, provision of improved indigenous chicken and poultry feeds } \\
\text { - Training of the women on poultry keeping } \\
\text { - Installation of solar energy for the village in centralized locations to ease communication }\end{array}$ \\
\hline Beekeeping & $\begin{array}{l}\text { Hamesa, Ozi } \\
\text { Golbanti, Nduru, } \\
\text { Hamesa, Hurara, } \\
\text { Onkolde and Shirikisho }\end{array}$ & $\begin{array}{l}\text { - Purchase and distribution of beehives } \\
\text { - Construction of apiary } \\
\text { - Purchase and installation of beehives } \\
\text { - Training on beekeeping and honey production }\end{array}$ \\
\hline Ecotourism & Ozi & - Purchase of engine for the boat and refurbishment of the boat for ecotourism \\
\hline Smart agriculture & Idsowe & $\begin{array}{l}\text { - Training of the women on smart climate agriculture } \\
\text { - Purchase and installation of smart agriculture technology-shed-net } \\
\text { - Initiation of tree nurseries }\end{array}$ \\
\hline Vegetable gardens & Moa & $\begin{array}{l}\text { - Fencing of the farm } \\
\text { - Provision of all farm inputs } \\
\text { - Purchase of a tank for the women }\end{array}$ \\
\hline
\end{tabular}

Respondents acknowledged that Nature Kenya's project supported IGAs have contributed up to $60 \%$ of household incomes in the beneficiary villages. The income generated has enabled households to acquire household assets as well as purchase food for their families. The support provided by Nature Kenya includes capacity building, provision of soft loans, provision of certified seeds of maize and green grams, and subsidized ploughing services for farming communities, construction of greenhouses, fish ponds and apiaries, and provision of milk storage equipment, beehives and solar panels to meet the household energy needs. 
Respondents alluded that they have gained skills following the numerous projects capacity building initiatives in improved farming methods (27\%), business management skills (23\%), best practices in beekeeping (15\%), marketing skills (11\%), good animal husbandry practices (11\%), environmental conservation skills (4\%), fish farming skills (1\%), and crop and livestock pests and disease management (1\%). Respondents, however, noted that they require more capacity building in accessing credit facilities and accessing competitive markets for their goods. Respondents further recommended that repeat pieces of training should be conducted and follow up visits done to enhance their skills for successful management of both existing and proposed new IGAs. Each village also recommended the use of Trainers of Trainers (ToT) as an appropriate strategy that should be used to enhance community skills in undertaking various income-generating activities as they transform the community to acquire the apple.

\section{Conclusions}

Farming was the main source of livelihood for communities living in Tana Delta. Although livestock keeping was the highest income-generating activity, they are owned by people living outside the Delta leading to less contribution to delta community livelihoods. The majority of the households in Tana Delta are either poor or very poor, with an average annual household income of Ksh. 71,466 and Ksh. 39,312 for male and female-headed households, respectively. The community acknowledged that there are a few households that are beyond the very poor who require special support to continue surviving. The participation of women in major income-generating activities, notably livestock keeping, savings and credit schemes and fishing and fish farming was low, hence the lower household incomes of female-headed households. Conflicts have had significant negative impacts on the livelihoods of communities living in Tana Delta. The conflicts are mainly resource-use conflicts driven by ethnic hatred, competing for land uses, competition over scarce water resources, and political interference.

Maize and rice were the most consumed foods by communities living in Tana Delta. Consumption of vegetables, fruits and pulses was generally low; this is a pointer to the poor nutritional status of the households. The low consumption of highly nutritious foods was attributed to the high cost of food that has seen households spend up to $90 \%$ of their income on food. Land demarcation, coupled with increased settlement and investment in the Delta, is reducing land for farming, grazing and wildlife areas. Availing land for sale may alienate the local communities with a possibility of escalating conflicts. The changing socio-economic development is compromising community climate change traditional coping systems.

The county government and development partners should invest more in technical support for agricultural development through inputs and specialized training. The partners need to initiate a multi-ethnic project as a means for 
building cohesion among communities. The CCA would provide means for conserving biodiversity but requires its ownership secured supported by inclusive CCA governance systems, adequate community awareness and consultations to ensure the buy-in of decision-makers and the real resource users.

\section{Acknowledgements}

The authors are very grateful to the Tana Delta community for allowing them to learn about their livelihoods and how they manage their natural resources. We acknowledge the support from all other stakeholders for sparing time to participate in the survey.

\section{Conflicts of Interest}

The authors declare no conflicts of interest regarding the publication of this paper.

\section{References}

[1] Langat, P.K., Lalit Kumar, L. and Koech, R. (2019) Understanding Water and Land Use within Tana and Athi River Basins in Kenya: Opportunities for Improvement. Sustainable Water Resources Management, 5, 977-987. https://doi.org/10.1007/s40899-018-0274-0

[2] Loucks, D.P. (2019) Developed River Deltas: Are They Sustainable? Environmental Research Letters, 14, Article ID: 113004. https://doi.org/10.1088/1748-9326/ab4165

[3] Vorosmarty, C.J., Syvitski, J., Day, J., Sherbinin A., Giosan, L. and Paola, C. (2009) Battling to Save the World's Deltas. Bulletin of the atomic Scientists, 65, 31-43. https://doi.org/10.2968/065002005

[4] Mireri, C. (2010) Tana River Delta (TRD) Conservation and Development Master Plan. Nature Kenya.

[5] Matiku, P. (2009) Tana River Delta. Conservation and Development Management Plan Draft for Discussion (Draft Version of 5 Nov 09).

[6] Government of Kenya (2018) Tana River County Second County Integrated Development Plan 2018-2022. Government Printer, Nairobi.

[7] Government of Kenya (2012) Tana River Delta Strategic Environmental Assessment, Scoping Report 2012. Ministry of Lands, Office of the Prime Minister, Ministry of State for Planning and National Development and Vision 2030 Secretariat, State House.

[8] Apostolides, A. and Moncada, S. (2015) Development Theory and Development in Practice: A Dialogue. NGO Support Centre, Nicosia, Cyprus.

https://www.um.edu.mt/library/oar/bitstream/123456789/41894/1/Development th eory and development in practice a dialogue 2015.pdf

[9] Reyes, E.G. (2001) Four Main Theories of Development: Modernisation, Dependency, World-System and Globalization. University of Pittsburgh, Pittsburgh. https://pdfs.semanticscholar.org/e36b/27f7b884e8b5a94d15c1382b99c8416af2ff.pdf

[10] Ministry of Agriculture (2013) Annual Report for Tana Delta District 2012. District Agricultural Office, Garsen, Tana River.

[11] Shiferaw, B. and Bantilan, C. (2004) Rural Poverty and Natural Resource Management in Less-Favored Areas: Revisiting Challenges and Conceptual Issues. Journal 
of Food Agriculture and Environment, 2, 328-339.

[12] Samoilys, M., Osuka, K. and Maina, G.W (2011) Review and Assessment of Biodiversity Values and Conservation Priorities along the Tana Delta-Pate Island Coast of Northern Kenya. CORDIO Status Report, CORDIO East Africa, Mombasa.

[13] Njuguna, S.G. (1992) Conservation of Biodiversity in Africa: Local Initiatives and Institutional Roles. Proceedings of the Conference, the National Museums of Kenya, 30 August-3 September, 1992.

https://www.oceandocs.org/bitstream/handle/1834/7694/ktf000e13.pdf?sequence $=2$ \&isAllowed $=\mathrm{y}$

[14] Baker, T., Kiptala, J., Olaka, L., Oates, N., Hussain, A. and McCartney, M. (2015) Baseline Review and Ecosystem Services Assessment of the Tana River Basin, Kenya. International Water Management Institute (IWMI), Colombo, Sri Lanka, 107 p. (IWMI Working Paper 165).

[15] Deere, C.D., Oduro, A.D., Swaminathan, H. and Doss, C. (2013) Property Rights and the Gender Distribution of Wealth in Ecuador, Ghana and India. Journal of Economic Inequality, 11, 249-265. https://doi.org/10.1007/s10888-013-9241-Z

[16] The World Food Programme (2018) Kenya County Strategic Plan (2018-2023). World Food Programme, Rome.

[17] Ministry of Health and Action against Hunger USA (2008) Nutritional Anthropometric and Mortality Survey Children Under Five Years of Age. Bangale, Madogo, Bura, Galole and Wenje Divisions, Tana River District, Final Report.

[18] National Drought Management Authority (2019) Status of Food Security in Tana River County. Government Printers, Nairobi.

[19] Kenya Red Cross (2015) Tana River Ethnic Conflict Situation Update No. 1 on 7th August 2015.

[20] Kipkemoi, S., Nyamasyo, G., Mari, N. and Musingi, J. (2017) Natural Resource-Based Conflicts in Tana River County, Kenya. International Academic Journal of Human Resource and Business Administration, 2, 599-610.

[21] Hanshi, N. (2017) An Analysis of Local Dynamics in Conflicts Over Use of Natural Resources in the Tana Delta Region, Tana River County, Kenya. 


\section{Appendix A: Perceived General Household Well-Being Ranking Indicators for Tana Delta Community}

\section{Rank A indicators: Rich}

- Ability to educate children up to college level

- Able to give a tithe

- Assists the public

- Has a maize milling machine

- Has three children

- Has the title for his land

- His decisions and authority are not opposed

- Income level of at least ksh. 300,000 p.a

- permanent house build with stones and tin-roofed house villages of Moa and Ozi

- Ownership of vehicle/s and motorbikes

- Owns 100 and 1000 herds of cattle

- Own between 10 and 200 goats

- Own between 50 and 400 sheep

- Owns a big shop, including a hardware

- Owns a business-shop, water vending kiosk, etc

- Own a farm of between 4 to more 15 acres with title

- Owns a ranch

- Permanent employment

- Owns rental houses in urban centres

- Takes three or 4 meals a day and can eat anytime he/she wishes

- Travel using a vehicle, motorbike or Tuktuk

- Use of at least 4 to 10 acres of land for farming in the farming villages

Rank C Well-being indicators: Poor

- Cannot give a tithe

- Casual worker

- Engages in the small scale business

- Has five children

- Has no farm

- House-made of mud and tin-roofed or mud-walled and grass-thatched hut

- Income level of between ksh. 50,000 - 100,000 p.a

- Take children up to primary level, but a few may educate children up to secondary with bursary support

- Meets his/her basic needs through a struggle

- Mostly travels on foot but occasionally uses a motorbike

- Own between 20 - 50 goats

- Owns a bicycle with a few owning at least a motorbike

- Ownership of between 30 - 100 livestock among the pastoral communities.

- Owns 5 and 20 sheep

- Owns a boat and fishing net of 400 to 800 yards

- Owns a farm of 1 acre

- Owns five chicken

- Owns less than 10 cows

- Sell milk and fried potatoes

- Takes 2 meals per day with some taking three meals a day

- Use of at least 2 acres of land for farming in the farming villages
Rank B indicators: Moderately rich

- Ability to educate children either to primary or diploma level

- Casual employment

- Have enough food and most take three meals a day with a few taking four meals

- Farms five acres

- Could have; a permanent house build with stones and tin-roofed, or grass-thatched and mud-walled house or house tin-roofed and earthen floor

- Has farming tractor

- Has four children

- Has one rental house

- Has two households (two wives)

- Income level of between ksh. 100,000 - 250,000 p.a

- Ownership of a motorbike or a car

- Ownership of between 100 - 800 livestock among pastoral communities

- Owns a motorbike

- Owns at least50 and 200 goats

- Own between 30 and 250 sheep

- Owns a shop

- Owns five acres without title

- Runs a small shop and butchery

- Ownership of between 1 - 4 boats among the fishing villages

- Travels using motorbike but occasionally walk

- Use of at least 5 acres of land for farming in the farming villages

Rank D Wellbeing indicators: Very poor

- Cannot afford bus fare but walks to all places

- Cannot take his children to school, but a few parents take their children up to primary with the support of relatives

- Does not have enough food and takes one meal a day

- Getting clothing is difficult

- Owns no land and in case he/she has it is less than 1 acre with no ownership documents, others have access to $1 / 2$ acre for farming and rely on rain-fed agriculture

- Grass thatched house with incomplete mud wall with some are accommodated by neighbours and relatives.

- Has many children

- Has no cattle or goats but few own 1 sheep, 10 Chickens, 2 Cows, 7 Sheep and 8 Goats

- Has no respect from the community

- Income level of approximately ksh 15,000 p.a

- Lack of (No ownership) fishing boats among the fishing villages

- Lack of (No ownership) land for farming in the farming villages

- Not assured of a meal and often times goes without a meal or eats once per day

- Not employed

- Ownership of a bicycle by a few

- Purely casual employees as they lack alternative sources of income

- Sales charcoal and firewood

- Survives through support from the community and tokens 


\section{Appendix B: FGD Perceived Community Livelihood Analysis}

\begin{tabular}{|c|c|c|c|}
\hline Livelihood source & $\begin{array}{l}\text { Gender involved } \\
\text { in the production }\end{array}$ & Challenges faced & Means of enhancing livelihood \\
\hline Basketry & $\begin{array}{l}\text { Women, Old Men } \\
\text { and Old Women }\end{array}$ & $\begin{array}{l}\text { - Difficulty in obtaining raw material, poor market } \\
\text { and exploitation by middlemen } \\
\text { - Inaccessibility of villages by buyers and poor road } \\
\text { network }\end{array}$ & $\begin{array}{l}\text { - Establish a trial plot for growing trees that } \\
\text { produce basket making raw materials } \\
\text { - Source for a reliable market }\end{array}$ \\
\hline Beekeeping & Men and Women & $\begin{array}{l}\text { - Theft of hives and honey, } \\
\text { - Inadequate skills on beekeeping and use of } \\
\text { traditional methods } \\
\text { - Transport cost to the market and poor prices } \\
\text { - Long drought spell hindering flowering of plants } \\
\text { - Lack of modern beekeeping equipment and } \\
\text { adequate protective harvesting gear }\end{array}$ & $\begin{array}{l}\text { - Provide farmers with harvesting equipment, } \\
\text { training on modern beekeeping technologies, } \\
\text { especially women and provide more beehives } \\
\text { - Provision of water } \\
\text { - Construction of an apiary } \\
\text { - Prevent forest fires } \\
\text { - Promote afforestation programmes }\end{array}$ \\
\hline $\begin{array}{l}\text { Bodaboda } \\
\text { (Motorbike } \\
\text { transport business) }\end{array}$ & Boys and Men & $\begin{array}{l}\text { - Activity is halted during the rainy season } \\
\text { - Too many motorbikes leading to a few customers } \\
\text { and low income } \\
\text { - Operators lack licenses } \\
\text { - Lack of a fuelling Centre and spare parts in the } \\
\text { village } \\
\text { - Poor road network } \\
\text { - The high cost of fuel }\end{array}$ & $\begin{array}{l}\text { - Improve road network } \\
\text { - Train riders, issue them with licenses, organize } \\
\text { them into riders cooperative societies } \\
\text { - Riders to be } \\
\text { - Create more income-generating activities } \\
\text { - Government to regulate fuel prices }\end{array}$ \\
\hline $\begin{array}{l}\text { BGOKers } \\
\text { (middlemen) }\end{array}$ & $\begin{array}{l}\text { Girls, Boys, Men, } \\
\text { Women and Old } \\
\text { Men. }\end{array}$ & $\begin{array}{l}\text { - School drop out } \\
\text { - Drug abuse } \\
\text { - Early marriage } \\
\text { - Laziness and ignorance }\end{array}$ & $\begin{array}{l}\text { - Provide skills } \\
\text { - Create awareness }\end{array}$ \\
\hline Business & $\begin{array}{l}\text { Girls, Boys, Men } \\
\text { and Women }\end{array}$ & $\begin{array}{l}\text { - School drop out } \\
\text { - Drug abuse } \\
\text { - Early marriage } \\
\text { - Laziness and ignorance } \\
\text { - Low business } \\
\text { - Less money in the village } \\
\text { - Poor and expensive transport means } \\
\text { - Wild animals prevent easy access to forest products }\end{array}$ & $\begin{array}{l}\text { - Impact modern business skills, especially to } \\
\text { youth to engage in business and gainful } \\
\text { employment } \\
\text { - Provide capital and skills }\end{array}$ \\
\hline Cash transfers & $\begin{array}{l}\text { Children, Old men } \\
\text { and Old Women }\end{array}$ & $\begin{array}{l}\text { - Irregular and delayed remittance } \\
\text { - Few beneficiaries } \\
\text { - Expensive to access due to long distances to the } \\
\text { market centre }\end{array}$ & $\begin{array}{l}\text { - Take children to school to get a good paying job } \\
\text { - Create local employment opportunities } \\
\text { - Monitor to ensure government cash transfers } \\
\text { reach recipients } \\
\text { - Have more beneficiaries }\end{array}$ \\
\hline Casual labour & $\begin{array}{l}\text { Girls, Boys, Men, } \\
\text { Women and Old } \\
\text { Men }\end{array}$ & $\begin{array}{l}\text { - Lack of skills, low wages and poor working conditions } \\
\text { - Less farm work due to drought } \\
\text { - Lack of employment opportunities } \\
\text { - Poor working conditions and lack of insurance } \\
\text { covers } \\
\text { - Child labour and defilement } \\
\text { - Overworking } \\
\text { - Unwanted pregnancies }\end{array}$ & $\begin{array}{l}\text { - Increase wages } \\
\text { - Establish small industries to create more } \\
\text { - Build a polytechnic to improve skills } \\
\text { - value addition I } \\
\text { - Provide capital }\end{array}$ \\
\hline Charcoal burning & $\begin{array}{l}\text { Boys, Men and } \\
\text { Women }\end{array}$ & $\begin{array}{l}\text { - Inadequate skills in charcoal burning, poor } \\
\text { technology, poor markets and prices } \\
\text { - Government regulations and police harassment } \\
\text { - Unavailability of medical facilities in case of injury } \\
\text { - Deforestation and destruction of animal habitat } \\
\text { - Risk of burns and health complications }\end{array}$ & $\begin{array}{l}\text { - Community sensitization on environment } \\
\text { conservation } \\
\text { - Training on appropriate charcoal production } \\
\text { technologies and produce charcoal sustainably } \\
\text { - Organize community into Charcoal Producer } \\
\text { Associations (CPAs) } \\
\text { - Advocate for improved prices and designate } \\
\text { market points } \\
\text { - Undertake re-afforestation }\end{array}$ \\
\hline
\end{tabular}




\begin{tabular}{|c|c|c|c|}
\hline Crop farming & $\begin{array}{l}\text { Children, Girls, } \\
\text { Boys, Men, Women, } \\
\text { Old men and Old } \\
\text { Women }\end{array}$ & $\begin{array}{l}\text { - Boys and girls missing schools } \\
\text { - Climate change } \\
\text { - Conflicts with pastoralists } \\
\text { - Drought and inadequate water } \\
\text { - Exploitation by middlemen } \\
\text { - The high cost of farm inputs } \\
\text { - Invasion of farms by wildlife/livestock } \\
\text { - Lack of extension services } \\
\text { - Lack of farm mechanization } \\
\text { - Lack of funds to facilitate farm activities like the hire } \\
\text { - of tractors } \\
\text { - Lack of irrigation equipment } \\
\text { - Low of seeds and pesticides } \\
\text { - Low rainfall } \\
\text { - Occasional destruction of crops by floods } \\
\text { - Over-reliance on traditional farming methods } \\
\text { - Pests and diseases } \\
\text { - Poor market } \\
\text { - Poor road network } \\
\text { - Wildife human conflict due to lack of fencing } \\
\text { - Women have other commitments } \\
\text { - Women lack ownership of farm produce }\end{array}$ & $\begin{array}{l}\text { - Availability of adequate water } \\
\text { - Construction of all-weather roads to link the } \\
\text { village to the market } \\
\text { - Enforcement of regulations on trespass } \\
\text { - Establish markets and ensure reasonable } \\
\text { market prices } \\
\text { - Establish cooperatives to assist in marketing } \\
\text { and provision of loans } \\
\text { - Establishment of livestock corridors through } \\
\text { the fencing of the farms } \\
\text { - Farmers to be provided with pesticides and } \\
\text { certified seeds } \\
\text { - Installation of solar panel in the farm } \\
\text { - Institute effective wildlife management } \\
\text { - The mechanization of farm activities } \\
\text { - Obtain aid from the county government } \\
\text { - Reduce the costs of farm inputs like certified } \\
\text { seeds and pesticides } \\
\text { - Provision of irrigation inputs(generators, pipes } \\
\text { and water pump } \\
\text { - Restore original river flow by blocking } \\
\text { - diversions } \\
\text { - Stop deforestation and sensitize on tree } \\
\text { planting }\end{array}$ \\
\hline Employment & $\begin{array}{l}\text { Girls, Boys, Men } \\
\text { and Women }\end{array}$ & $\begin{array}{l}\text { - Lack of skills and employment opportunities } \\
\text { - Child labour } \\
\text { - Overworking and low salary } \\
\text { - Insecurity } \\
\text { - Poor transport } \\
\text { - Government regulations such as paying tax } \\
\text { - Low level of education and poor working conditions } \\
\text { - Conflicts between Government and workers }\end{array}$ & $\begin{array}{l}\text { - County government to come up with } \\
\text { - alternatives employment opportunities } \\
\text { - Offer better salaries } \\
\text { - Improved security } \\
\text { - Ensure a good road network } \\
\text { - People to be more educated and trained } \\
\text { - Government to improve all sectors } \\
\text { - Government to address works conflicts } \\
\text { through the labour department }\end{array}$ \\
\hline $\begin{array}{l}\text { Fishing and fishing } \\
\text { business }\end{array}$ & $\begin{array}{l}\text { Boys and Men, Old } \\
\text { men and women }\end{array}$ & $\begin{array}{l}\text { - Attack by hippos and crocodiles } \\
\text { - Boys lack ownership of fishing gears } \\
\text { - Child labour } \\
\text { - Children missing school } \\
\text { - Destruction of fishing gear by crocodiles } \\
\text { - Drought and drying of lakes and rivers lowering fish } \\
\text { - } \text { Fatches } \\
\text { - Highermen lack insurance } \\
\text { - Lack of proper fishing skills and fishing gears } \\
\text { - Long-distance from the fishing area } \\
\text { - Low catch and overfishing } \\
\text { - Poor market and poor prices } \\
\text { - Poor road network making it difficult reaching } \\
\text { - } \text { market } \\
\text { - Saltwater mixing with freshwater limiting the } \\
\text { - Seasonality of the fishing sector } \\
\text { - Exploitation by middlemen } \\
\text { - Lack of storage equipment }\end{array}$ & $\begin{array}{l}\text { - Introduce fish farming, construction of } \\
\text { - } \text { Prshponds and provide appropriate fishing gear } \\
\text { - Construction of fish storage facilities } \\
\text { - Ensure accessibility of the village by buyers } \\
\text { - Provision of proper fishing gears and storage } \\
\text { equipment } \\
\text { - Introduce better fish breeds } \\
\text { - Restore original river flow } \\
\text { - Prevent boys from fishing } \\
\text { - Build more fish market } \\
\text { - Provide capital } \\
\text { - Rehabilitation of dried lakes and degraded } \\
\text { mangrove areas } \\
\text { - Restoration of river flow } \\
\text { - Train community on fish farming, modern } \\
\text { fishing technologies, value addition and } \\
\text { marketing }\end{array}$ \\
\hline
\end{tabular}




\section{Continued}

\begin{tabular}{|c|c|c|}
\hline $\begin{array}{l}\text { Government } \\
\text { employment }\end{array}$ & Men, women & $\begin{array}{l}\text { - Inadequate employment opportunities } \\
\text { - Low education levels }\end{array}$ \\
\hline $\begin{array}{l}\text { Livestock (chicken, } \\
\text { goats and ducks) }\end{array}$ & All Gender & $\begin{array}{l}\text { - Children missing school } \\
\text { - Conflicts between farmers and livestock keepers } \\
\text { - Human/wildlife conflict } \\
\text { - Drought and inadequate water } \\
\text { - Lack of veterinary services and the high cost of } \\
\text { - drugs } \\
\text { - Insufficient land for grazing and modern animal } \\
\text { - Insecurity } \\
\text { - Lack of finance } \\
\text { - Lack of ownership by women } \\
\text { - The long-distance involved scaring away women } \\
\text { - Loss of livestock } \\
\text { - Poor market and diseases } \\
\text { - Women have to balance between livestock keeping } \\
\text { with other duties }\end{array}$ \\
\hline
\end{tabular}

- Provision of bursaries for college education

- Construction of a slaughterhouse

- Control influx of livestock from other counties

- Designation of grazing areas away from farms

- Ensure proper housing and disease control

- Establish a market for livestock

- Establishment of pasture sources

- Exploring other alternatives such as irrigation farming

- Fence farms

- Fencing of the dam

- Form marketing cooperatives and promote livestock marketing schemes

- Construct a slaughterhouse to enhance value addition

- Government to improve security and culprits to be punished

- Introduce poultry farming

- Keeping hybrid animal breeds

- Livestock offtake programs supported by proper animal stocking

- Avail and lower price of drugs, vaccines and pesticides

- Planting livestock feeds and feed storage

- Provision of grazing land

- Provision of water and specific watering points

- Strengthening local ranches

- To obtain funds through loans.

- Use of indigenous knowledge

- Veterinary officers to be available

- Increase wages

- Establishment of village polytechnics

- Availability of markets

- Making more people benefit

- Improve farming

Relief food

Men, Women, Old men and Old Women

- Only given to a targeted group of age
- Not reliable and quantities insufficient

- Not predictable

- Not enough to meet the needs of the beneficiary Men, Women, Old • Delay in disbursement Men and Old

- A small fraction of beneficiaries

- Huge transaction cost

- Separation and break up of families

- Lack of pasture

- Drought

Boys, Women and $\bullet$ Low milk production Old Women

- Poor handling of milk

- Price fluctuation

- Low market and poor prices

Sale of forest products

Men and Women

- Government regulations

- Exposure to dangerous snakes and insects

Sale of water

Women and Men

- Inadequate supply
- Increase employment opportunities

- Take children to school to get a good paying job

- Provision of ice cubes and cool boxes

- Purchase of milk handling equipment

- Organize groups into cooperatives for milk business

- Create awareness on forest access regulations

- Encourage value addition and provide a market for products

- Drilling of wells and distributing piped water 


\section{Continued}

\begin{tabular}{|c|c|c|c|}
\hline $\begin{array}{l}\text { Small business } \\
\text { enterprises (kiosk) }\end{array}$ & $\begin{array}{l}\text { Girls, Boys, Men, } \\
\text { Women, Old men } \\
\text { and Old Women }\end{array}$ & $\begin{array}{l}\text { - High transport cost and poor road network that } \\
\text { limits access to wholesale markets } \\
\text { - Inadequate capital and vulnerability of business } \\
\text { capital to other uses } \\
\text { - Low purchasing power Long distances that raise the } \\
\text { - } \text { price of commodities } \\
\text { - Governity and conflicts } \\
\text { - Late payment of goods taken on credit }\end{array}$ & $\begin{array}{l}\text { - Training on civic, financial and business skills } \\
\text { - Introduction of loaning schemes } \\
\text { - Construction of village market } \\
\text { - Repair the roads to improve the accessibility of } \\
\text { the village and lower transport costs } \\
\text { - Enhanced co-existence in the community } \\
\text { - Government to improve security } \\
\text { - Improving the economy and living standards } \\
\text { - Increase production capacity in the local area } \\
\text { - Use of speed boat during flooding }\end{array}$ \\
\hline Table banking & $\begin{array}{l}\text { Girls, Women and } \\
\text { Old Women }\end{array}$ & $\begin{array}{l}\text { - Savings not done on time } \\
\text { - Low ability to repay loans }\end{array}$ & - Ensure loan repayment in done promptly \\
\hline
\end{tabular}

\section{Appendix C: Community Perceived Conflicts through FGD}

\begin{tabular}{|c|c|c|c|}
\hline Conflict type & Village experienced & Causes & Mitigation \\
\hline $\begin{array}{l}\text { Farmers versus } \\
\text { Pastoralists (Livestock } \\
\text { grazing in farmlands and } \\
\text { farmers farming in } \\
\text { grazing areas) }\end{array}$ & $\begin{array}{l}\text { Chaluma, Handaraku } \\
\text { Didewaride } \\
\text { Hewani } \\
\text { Hurara } \\
\text { Nduru } \\
\text { Ozi } \\
\text { Onkolde } \\
\text { Moa }\end{array}$ & $\begin{array}{l}\text { - Inadequate grass leading to livestock } \\
\text { grazing in farms leading to clashes } \\
\text { between farmers and cattle keepers } \\
\text { - The killing of livestock by farmers } \\
\text { and the destruction of food crops } \\
\text { killing of livestock leading to ethnic } \\
\text { conflicts }\end{array}$ & $\begin{array}{l}\text { - Provide grass to livestock keepers } \\
\text { - Create awareness to communities to exist and train } \\
\text { them in leadership and management } \\
\text { - Farmers to stop killing livestock } \\
\text { - Put aside land for farming } \\
\text { - Reduce the number of livestock } \\
\text { - Designate livestock grazing areas, routes, grazing } \\
\text { areas and watering points } \\
\text { - Prayers } \\
\text { - fencing of farms and homesteads } \\
\text { - Implemention of parks and wildlife corridors of the land use plan } \\
\text { - Land ownership through title deeds issuance } \\
\text { - Limit the number of livestock } \\
\text { - Create national parks }\end{array}$ \\
\hline Human-wildlife conflict & $\begin{array}{l}\text { Chaluma, Handaraku, } \\
\text { Golbanti, Bularahma } \\
\text { Didewaride } \\
\text { Nduru } \\
\text { Ozi } \\
\text { Onkolde } \\
\text { Moa }\end{array}$ & $\begin{array}{l}\text { - Wildlife killing humans, livestock } \\
\text { and destroying crops } \\
\text { - People moving at night being hurt }\end{array}$ & $\begin{array}{l}\text { - Create awareness on farmers not to kill wildlife and } \\
\text { how to co-exits } \\
\text { - Create barriers between farmers and cattle Land } \\
\text { adjudication } \\
\text { - Fencing farms to prevent wildlife } \\
\text { - Provide more security to farmers } \\
\text { - Proper management of CCAs } \\
\text { - Increase KWS personnel to ensure adequate control } \\
\text { - } \text { Preasures } \\
\text { - Creating wildlife corridors } \\
\text { - Create an animal sanctuary }\end{array}$ \\
\hline Land & $\begin{array}{l}\text { Handaraku, Golbanti } \\
\text { Hewani } \\
\text { Nduru }\end{array}$ & $\begin{array}{l}\text { - Degradation of forest } \\
\text { - Influx of outsiders } \\
\text { - Land grabbers at lower Tana }\end{array}$ & $\begin{array}{l}\text { - Sensitize community on the benefit of co-existence } \\
\text { - Invaders to go back to their motherland } \\
\text { - Stop the creation of salt farm } \\
\text { - Get court orders to remove land grabbers }\end{array}$ \\
\hline Ethnic conflicts & $\begin{array}{l}\text { Golbanti, Bularahma } \\
\text { Didewaride } \\
\text { Hewani } \\
\text { Shirikisho }\end{array}$ & $\begin{array}{l}\text { Competition for land, water and } \\
\text { pasture }\end{array}$ & $\begin{array}{l}\text { - Land adjudication and issuing of title deeds } \\
\text { - community elders to create peace } \\
\text { - Engaging the Government at national and county } \\
\text { level } \\
\text { - Provision of adequate resources like bulking grass to } \\
\text { use in dray areas and provision of hay }\end{array}$ \\
\hline
\end{tabular}


M. T. E. Mbuvi et al.

\section{Continued}

\begin{tabular}{llll}
\hline Family conflicts & Hewani & Family property & - Elders and training on Gender \\
$\begin{array}{l}\text { Intra gender inequity in } \\
\text { income }\end{array}$ & $\begin{array}{l}\text { Ozi } \\
\text { Idsowe }\end{array}$ & $\begin{array}{l}\text { Lack of employment } \\
\text { Marketing of produce }\end{array}$ & $\begin{array}{l}\text { - Training of youth and women groups } \\
\text { - Companies employing locals }\end{array}$ \\
Weather & Ozi & Drought & - Buy a pump to facilitate access of water from the river \\
& & & for irrigation \\
Religious & Shirikisho & & - Create more awareness \\
Fishing & Shirikisho & fishing ponds and swamps & gration \\
Political & Idsowe & & - Construct fish ponds
\end{tabular}

